\title{
On the Politics of Lockdown and Lockdown Politics in Africa: COVID-19 and Partisan Expedition in Ghana
}

\author{
Awaisu Imurana Braimah \\ Department of Political Science Education, University of Education, Winneba, Ghana \\ Email address: \\ baimurana@uew.edu.gh \\ To cite this article: \\ Awaisu Imurana Braimah. On the Politics of Lockdown and Lockdown Politics in Africa: COVID-19 and Partisan Expedition in Ghana. \\ Journal of Political Science and International Relations. Vol. 3, No. 3, 2020, pp. 44-55. doi: 10.11648/j.jpsir.20200303.11
}

Received: June 2, 2020; Accepted: June 24, 2020; Published: July 6, 2020

\begin{abstract}
This article examined the lockdown jigsaw that characterised Ghana's surveillance and management of the COVID-19 pandemic. While the main opposition political party - National Democratic Congress (NDC) - and the Ghana Medical Association (GMA) in particular advocated a total shutdown of the country in a bid to contain the spread of the virus, the government in March, 2020, announced a partial lockdown of specific cities and suburbs where the virus was endemic for a period of 21 days. In the process, the government embarked on an aggressive contact tracing and test that catapulted the number of confirmed cases in March, 2020, from 2 to 7,303 as at May 27, 2020. The government subsequently, lifted the partial lockdown to ease the suffering of the vulnerable masses in society while strictly observing social or physical distancing and other protocols advocated by the World Health Organisation (W. H. O.) and the Ghana Health Service (G. H. S). The lifting of the restrictions by the President of the Republic, attracted varied reactions from the populace and some interest groups. While the vulnerable and the 'have-nots' in society whose survival is contingent on daily economic hustle and bustle in the city hailed the lifting of restrictions, the elites and economic self-dependent individuals on the other hand, criticised the government for lifting the partial lockdown. This paper argues that the partial lockdown and the subsequent lifting of the restriction on movements, was premised on the machinations of politics, economics and science.
\end{abstract}

Keywords: Coronavirus, Lockdown Politics, Pathogenic Disease, Partisan Expedition, Vulnerable

\section{Introduction}

Global public health has emerged in recent times as a central concern of the international development effort to deal with infectious diseases, eliminate stark poverty and strengthen educational and cultural ties internationally [1]. Globally, the coronavirus eruption has shemozzled and clearly, dead ahead puzzle for both developed and developing economies. This is because, the emergence of the coronavirus in China was previously unknown to scientists globally [2] Consequently, the pandemic has put developed and developing economies in a scratch race to develop appropriate containment strategies (e.g., medications and vaccines) to halt the devastating effects of the virus on human life and the crippling global economy. States are aggressively and unrepentantly pursuing 'draconian' policies, such as restriction on human movements, social distancing, stay at home directives, shutdown of businesses and services in the manufacturing sector, retail outlets, restaurants, the stock exchange, transport systems, beauty parlours or salons, night clubs, sporting events, educational institutions and agribusinesses among others. Job losses, stark poverty, hunger, the fear of the unknown, inability to pay rent and other bills, family pressure, and panic, as the death toll rises exponentially across the world. These are some of the prominent features of lockdowns or restrictions in the wake of the COVID-19 pandemic. The restrictions imposed on national populations globally, turned out to be unpopular, and triggered tea party protests across the United States (where over 40+ million Americans lost their jobs), Germany, India, the United Kingdom, Sweden, Spain, Poland, Belgium, South Korea, Iran, Nigeria, Kenya, etc. The Presidents of the United States and Brazil for example, openly supported citizens via speeches to protest against Governors and Local authorities to lift restrictions and reopen economies. The action of President Trump for instance, has rekindled partisan politics between the Conservatives and the Democrats in the midst of a pandemic that continuously wreaked havoc on 
human and economic life of states. In Brazil for instance, the handling of the coronavirus disease by the government has rekindled extreme partisan politics from the national to the local level. The Minister of Health who expressed a contrary view to that of the President on the reality of the virus and its management or handling style, was fired from his post. In the process, Brazil overtook the United States in terms of daily infection rate case count, and death toll.

In Africa, the spike in COVID-19 cases across the continent is gradually peaking at an exponential rate. According to Brown and Wang (2020), 'the spread of the disease around ... the globe, is a multilayered issue that affects both politics and science' [3] In order to contain the importation and subsequent community infections and spread of the virus, some African countries blocked all entry points into their countries by land, air and sea; imposed restriction on movements of people; closed down businesses; sporting events; hospitality industry; transportation educational institutions and their like. These lockdowns necessitated the announcement of various stimulus packages by governments to first, aid the impoverished and the vulnerable in society, and second, to assist small scale businesses to keep their heads above water. The main aim of the various stimulus packages were to protect jobs of compatriots in the informal sector, and, to further reduce or cushion the harsh effects of the lockdowns on individuals, dependents and families. While announcing these packages, some states engaged global Financial Institutions like the International Monetary Fund (IMF), the World Bank (WB) and the African Development Bank (AfDB), for quick loans, in order to combat the virus and the resulting consequential issues. The South African President announced a 500 billion-rand (approximately, US\$28 billion) stimulus package. While these reliefs across the continent were applauded, implementation in some countries delayed, due to some bureaucratic processes (i.e. approval of parliament and assent of political leadership) involved in the approval and release of funds. In the process, many citizens across Africa were left to starve. The social distancing which is one of the key protocols advocated by the World Health Organisation (W. H. O), became a luxury for the poor and homeless (e.g. Nigeria, Kenya, South Africa, Ghana, Zimbabwe), as they scamper for limited foodstuffs released by the various governments. Lockdown of businesses (especially in the informal sector where the overwhelming majority of Africans engage in petty trading) and restriction on people's movements in Africa, has the potential to kill more people than the coronavirus, if adequate stringent measures are not put in place to change the status quo.

In the Ghanaian context, the government put in place a taskforce comprising Health Professionals, personnel from the Immigration Service, Police Service and the Military, designated as frontline workers. The main function of the taskforce was/is to check the spread of the pandemic through routine surveillance, testing, contact trace and the management of confirmed cases. The main opposition political party (N. D. C), immediately responded by setting up a parallel team on COVID-19 to 'assist' in the combat of the pandemic. The NDC team, through its flag bearer, made very timely donations in the form of Personal Protective
Equipment (PPEs), hand sanitizers, washing soap and other items to some key health institutions in Accra to complement the efforts of the government. The donations were done at a time the PPEs were in short supply globally. While presenting these PPEs, the former President (i.e., John Dramani Mahama), gave alternative policy directions to the government on COVID-19 management, while the minority caucus in Parliament were busily scrutinising every financial deal the government sought to secure in lieu of the pandemic; albeit, with partisan expeditious lenses to score political points. According to Biscop (2020), in democracies, governments that fail to act timely and decisive during a pandemic, will most likely lose the next elections to political opponents [4]. For, political opponents will usually undermine the efficacy of government policies and actions during public health crisis

Another bold but difficult decision the government of Ghana took as one of the key measures to combat the spread of the virus, was an imposition of a partial lockdown with a flexible restriction on movements of people only when very necessary in areas designated as coronavirus endemic. The decision for a partial lockdown took a partisan political twist. The largest opposition political party - the National Democratic Congress (N. D. C) - criticised the government for the partial lockdown. The NDC advocated a total lockdown or curfew as an effective means to control the spread of the virus. The politicking on partial lockdown and total lockdown jigsaw, almost took the shine out of the collective effort of Ghanaians to defeat coronavirus. To minimise the scorching effects of the partial restriction imposed on the movement of a section of the Ghanaian populace and subsequent loss of livelihoods, the President of the Republic, announced further relief packages, such as absorption of three months (April, May and June) water bills of the citizens and the cost of electricity of lifeline customers; and a further $50 \%$ reduction in the cost of electricity for the rest of society for the same months - April, May and June, 2020. A free hot meal a day for the downtrodden, homeless, poor and needy people in the endemic communities was rolled out. In spite of the well-intentioned plans of the government to cushion the people from the hardships and misery, the distribution of the food to the vulnerable in society, started on a wrong footing. The estimated number of 400,000 the state intended to feed, skyrocket to more than double of the figure. The Ministry of Gender and Social Protection and the Ministry of Local Government narrowly operationalized the 'vulnerable' and 'poor in society' to mean, homeless head porters, beggars on the street and slum dwellers dotted around the capital city of Greater Accra, Kasoa and Greater Kumasi. In the end, plantain sellers, cobblers, salon operators, mechanics, dressmakers, drivers, petty traders, hotel and restaurant workers whose survival depend on daily minimum wage, and others who tragically lost their jobs, all joined the fray with family members to scramble for the food being distributed by the government and other faith-based organisations. Hence, the unexpected bloating of the numbers led to accusations and counter 
accusations of the food being distributed on partisan political basis. In other words, the poor, nee dy and the homeless were denied food on the pretext that, they were not supporters of the governing New Patriotic Party (NPP). This accusation was vehemently denied or refuted by government officials. The daily expenditure on food to the so-called vulnerable in society, was estimated at GHS 2 million. A figure the state purse by all intent and purposes, could not shoulder for three (3) consecutive months without financial inflows from import and export duties, levies, taxes on remittance from abroad and businesses, etc.

This paper presents two key arguments. First, the manner in which public health issues (e.g. COVID-19, Cerebrospinal Meningitis or CSM for short, etc) suddenly became inextricably partisan political expedition between the governing NPP, and the largest opposition political party, the NDC. The latter maintains that, the policy or decision of the government to impose partial lockdown, and subsequently lifting the restrictions on the movements of citizens to stem the spread of COVID-19, was a monumental policy failure. The former appraised its decision to end the partial lockdown originally imposed as the finest, and based on scientific data available to the President of the Republic. Second, the interrogation of the politics, economics and scientific basis that culminated in the lifting of restrictions by the government. On the basis of these arguments, the following research questions were posed to guide the study.

1. To what extent is COVID-19 pandemic assumed partisan political undercurrent in Ghana?

2. What is the politico-economic and scientific basis of lifting restrictions in Ghana?

\section{Methods of Data Collection}

The study was structured to examine policies and/or decisions on COVID-19 partial lockdown and total lockdown politics involving the governing NPP, the opposition NDC, elites, and the poor and vulnerable masses in the Ghanaian society. The target population for this study was entirely, all vulnerable persons, party officials, and the elites in the study areas. Consequently, data and information for the study was gathered from two key sources. The primary source was obtained from 140 participants randomly recruited through convenience sample from the entire population. The driving force behind this study was to solicit the views and perceptions of political parties (members of the NPP and NDC), elites, the poor and vulnerable in society on the lifting of the restrictions after having been in force for three (3) weeks. Consequently, data and information was obtained from three main categories of respondents or participants viz, members of political parties, the elites, the poor and vulnerable in society in the capital city of Accra. The study area or suburbs for the vulnerable persons were: Agbogboloshie, Chorkor, and Nima. Party officials were randomly selected from Districts and Regional offices in Accra, while the elites were randomly selected from East Legon, Adenta, and Dzorwulu also in Accra.
In this perspective, 140 participants were recruited: thus 90 from the vulnerable/poor in society; 30 respondents drawn from the elites in society; and 20 respondents made up of party officials. The table below summarizes the category of respondents and the average age of participants.

Table 1. Category of Respondents.

\begin{tabular}{llll}
\hline S/N & Category of Respondents & $\begin{array}{l}\text { Number of } \\
\text { Participants }\end{array}$ & $\begin{array}{l}\text { Average } \\
\text { Age }\end{array}$ \\
\hline 1. & Vulnerable/Poor in society & 90 & 26 \\
2. & Elites/Affluent & 30 & 38 \\
3. & Party Officials & 20 & 36 \\
& Total & 140 & \\
\hline
\end{tabular}

Source: Field Notes, 2020.

This study is purely qualitative. The method was adopted because, it enables immense interaction between the researcher and respondents. Further, qualitative method affords the researcher the opportunity to acquire first-hand information about the respondents through frank and openended inquiry. Hence, the key instrument adopted for this study was face-to-face interaction and/or interview sessions with participants. The rationale for adopting this approach in data collection was to first, get a near-live situation from the perspective of the poor and vulnerable in society who, welcomed government's decision to ease the restrictions. Second, many of the poor and vulnerable in society are unlettered to effectively complete a questionnaire. Same data collection approach was used for both the elites and party officials. Permission was granted by respondents to record proceedings for posterior transcription and for analytical purposes. Out of the total number, 80 participants, representing $57.1 \%$, were females, while 60 participants, representing $42.8 \%$, were males. Secondary data was utilized to complement the primary data and information gleaned from journal articles and books. The secondary data was subjected to further reliability test to ensure accurate evaluation and interpretation based on the varied responses gathered from the participants of the study.

The study was anchored on two thematic areas about COVID-19 pandemic and lockdown politics. Questions included the following: partisan political expedition and the politics, economics and scientific rationale for partial lockdowns and total lockdown jigsaw that characterized Ghana's quest to defeat the novel coronavirus pandemic. The researcher employed a multifactorial analysis to unearth the 'real' driving force in lifting the restrictions in Ghana on April 20, 2020 [5].

\section{Discussion of Findings}

The thrust of this study was to explore variations in thought overtime (i.e., three weeks lockdown) in the lifting of restrictions [6]. The varied participants (i.e., poor and vulnerable, elites and officials of political parties) of this study on COVID-19 revealed divergent views on the politics of partial lockdown and total lockdown politics. On the basis 
of the lifting of the restrictions, participants expressed different views, especially among the elites and party officials. The results derived from the responses of the respondents are thematically categorised according to the varied participants - poor and vulnerable, elites and party officials as summarised below:

\subsection{Poor and Vulnerable in Society}

The poor and vulnerable persons had full grasp of the essence of the lockdown, its economic, political, health and psychological implications. It was found out that, many of the poor and vulnerable in society had no access to government's relief packages such as cooked food, raw foodstuffs, water and other largesse to keep them afloat during the partial lockdown. For the poor and vulnerable in society, the lockdown was synonymous to misery, starvation, abject poverty, and unyielding pressures from the nuclear and extended family systems.

One of the key findings of this study was that, the partial lockdown imposed by the government was very unpopular among the poor and vulnerable persons and their communities. Many of them had resorted to 'begging' from their immediate neighbors in the partial lockdown period for survival. The cooked food distributed, did not either get to, or suffice the intended target population or groups. Many of the poor and vulnerable persons in the study communities have dependents ranging from a minimum family of three (3) to a maximum of seven (7). One of the participants succinctly summarised the complex frustrations under the partial lockdown period as follows:

I have a family of six. On a daily basis, I am able to scramble to get one pack of cooked food distributed by the Local Assembly or government. How can a family like mine depend on one packed food? If the government had extended the partial lockdown for another one week or more, many of us would have died from starvation other than the coronavirus. We were jubilant on the streets in support of the government's decision to lift the restriction on movements. I am a cobbler and my wife sell sachet water to support the family. Lifting the restrictions means, we can return to business, and make some money to take care of our children and other responsibilities.

Another participant expressed the following sentiments:

We thank the government for lifting the restrictions. We were starving during the partial lockdown. The government's food never got to us. Those distributing the food we suspect, denied us the food because of our perceived political affiliation. This was what the NDC constituency office told us. Whether it was true or not, we never got the food and other relief packages especially water.

The study found out that, the partial lockdown had security implications. Gleaning from the responses from the participants, an extension of the lockdown would have created civil defiance on the part of the poor and vulnerable in society. Some political elements unpatriotically organised some of the poor and the vulnerable youth to embark on a series of violent demonstrations on the basis that, government discriminated against perceived political opponents in the distribution of food packages. They stated inter alia that:

We were readying ourselves to embark on demonstrations against the government and the security agencies had the partial lockdown been extended. The demonstrations were going to be staged mainly in the capital city, dubbed: "It is better to die from coronavirus than hungervirus". Resources of course, were going to be provided by some politicians. You know we can't mention their names to you. We were going to do this to get the government to distribute food fairly to those in need and not their party supporters. Didn't you hear some MPs complaining about the unfair distribution of food to only NPP supporters?

Participants also expressed views on the rationale or basis for lifting the restriction on movements. 77 out of the 90 participants (representing $85.5 \%$ ) were of the view that the government eased the restrictions to ameliorate the suffering of the poor and vulnerable in society. According to the respondents:

The President lifted some of the restrictions because, he wanted those of us who cannot afford to stock food for even two days to go back to work. The government too could not feed all of us as promised. Cobblers, trotro drivers, plantain sellers, prostitutes or commercial sex workers, private security guards, taxi drivers, hawkers and truck pushers in the various markets who lost their jobs as a result of coronavirus, joined the fray of the poor, vulnerable and needy in society. The government could not have fed all of us. There was therefore the need to lift the partial lockdown.

However, 13 participants designated as the poor and vulnerable in this study (representing 14.4\%), could not tell the basis on which the government lifted the restriction on movements. They were of the view that, only government officials could offer a better explanation. According to the participants:

We don't have any evidence to show the reason behind lifting the restriction on movements. But some people are saying it was political and others are of the view that it was economic. For us, the most important thing is that, the restriction has been eased; and we can now enjoy our freedom of movement. In fact, if the government had extended the partial lockdown, we don't know what would have happened to us. The lockdown was not good. But we thank the government for lifting the restriction on movements. We will be able to work now to feed ourselves, for hunger and starvation kills.

\subsection{Elites in Society}

The responses of these category of participants revealed a clear-cut understanding of the issue understudy. In general, participants were of the view that the lifting of the restrictions was premature and a recipe for disaster (unbridled spread of the virus). However, some of the participants who are also entrepreneurs were ambivalent. At 
one breadth, they supported the government's decision for lifting the ban on movements; and in another, expressed fear of the possible spread of the pandemic. 23 out of the 30 participants (representing 76.6\%) supported government's decision to lift the restriction on movements. They contend among others that:

We support the government for easing the restrictions. As business people, we are losing out. We can't afford to pay the salaries of our employees for the months of March and April, 2020; repay loans contracted from banks; and other bills, including rent. Those of us in the pharmaceutical industry risks having our products getting expired. There are lots of perishable goods locked up in the warehouses. Hence, lifting the restrictions may help businesses to bounce back slowly. We are not however sure if it is safe to work in the midst of the coronavirus pandemic. Whether the easing of the restrictions was based on political, economic and scientific evidence that is not a major problem to us. The key issue is that, the restriction on movement has been lifted and economic life of the state and individuals will gradually be restored. Politicians will continue to twist matters and issues for parochial interests.

Participants raised concerns about the positive impact of the COVID-19 pandemic and the easing of the movement restriction. According to four (4) participants,

COVID-19 should not be viewed only in the negative limelight. It is an opportunity for states across the world to massively invest in their healthcare systems. The so-called developed countries with well-equipped healthcare systems, are caught panties down. COVID-19 also teaches world leaders a very useful lesson. The need to invest in ICT in all sectors of the economy, including education and industry. Families have been reunited; many others have 21 days of rest with the family. COVID-19 is not all that bad even though, some recorded losses are bound to happen in all sectors of the economy.

However, seven (7) out of the 30 respondents (representing $23.3 \%$ ) in this category, were not enthused with the government's decision to lift the restriction on movements. They were of view that, the virus spread will increase or grow exponentially. According to one of the participants:

The lifting of the restrictions was unexpected. It came as a surprise to me and my family. Why will the government lift the ban at a time COVID-19 was spreading very fast in the country? Opening up the economy at this material moment was a bad decision. The slum areas in Accra may be agents of the spread of the virus. They are densely populated, and cannot practice social or physical distancing. They will then eventually spread the virus to every part of the capital or country. I don't think the lifting of restriction was based on any scientific data. I strongly believe politics influenced the decision of the government to ease the restriction. Well, the financial implications of the partial lockdown could also be the reason. But let's think of our health first before other considerations.

\subsection{Officials of Political Parties}

Interaction with this category of respondents showed understanding of the prospects and pitfalls of the coronavirus pandemic. They however, differ remarkably in the approaches adopted by the government in the management of the pandemic. Party officials in the context of this study, were limited to the NPP and the NDC. For, the two political parties were/are identified to unrepentantly, engage in the COVID-19 politicking. This was manifested in their various responses. Both parties accused each other of engaging in partisan politics to score 'cheap' political points.

The study revealed that, the NDC was very much uncomfortable with the communication machinery of government appointees. According to the participants, government communicators used the COVID-19 platform to spread 'falsehood' about the performance of the ruling NPP government in the health sector. By so doing, they are involved in marketing, and campaigning for votes in the upcoming Presidential and Parliamentary elections slated for December 7, 2020. According to some NDC party officials:

The President and his appointees are doing subtle politics with the pandemic. The government has been using the COVID-19 platform to engage in propaganda at a time the NDC can't be on any campaign trail to engage Ghanaians. For instance, the Health and Information Ministries always tout the achievements of President Akufo-Addo in the health sector, including facilities built by former President John Dramani Mahama, without any credit or recognition given to his predecessor This, we consider as an attempt to usurp projects initiated and executed by the NDC. Do you expect the NDC to keep mute? The ruling NPP government must focus on the pandemic and should desist from playing politics with it. We will continue to counter their lies if they don't stop. How can 88 new hospitals be built within one year across the country? It is their secret 2020 political manifesto they are rehearsing and explaining to Ghanaians.

On why the lifting of the partial lockdown by the government? The NDC officials were of the view that, it was all about politics and not any other consideration. The government short-changed the health of Ghanaians for political expedience. The government 'feared' that, the temporary economic hardships it unleashed on the good people of Ghana would affect its electoral chances. It failed woefully to honor its promise of providing food to the poor and vulnerable during the partial lockdown. Hence, the lifting of the restriction on movements. In the opinion of some NDC party officials:

The NDC is vindicated in challenging the basis for the lifting of the partial lockdown. The fast spread of the disease across the country is an ample demonstration of the NPP government's incompetence. The numbers have jumped from 834 at the time of the lifting of restrictions to more than eight-fold (Confirmed cases of 7, 303 as at May 27, 2020) according to the Ghana Health Service (G. H. $\mathrm{S})$. Surprisingly, the NDC is rather branded as engaging in 
politics with the pandemic. The disease is no respecter of persons, political colors, and place of origin. The lifting of the partial lockdown was purely political, and a cover up of the government's failure to care for the poor and vulnerable persons in society during the partial shutdown. The NDC is surprised that most civil society organisations are quiet about the way the government is mishandling the COVID-19 pandemic.

In contrast, the ruling New Patriotic Party accused the NDC of engaging in misinformation about COVID-19 with the intent to instil fear and panic among the citizens. These acts according to the NPP, were meant to score undeserved political points. The NDC's opposition regarding lifting of the restriction of movements was nothing but 'hypocrisy' of the highest order. This was a party that was highlighting and drawing government's attention to the suffering masses as a result of the partial lockdown. The same NDC has now made a sudden "U-turn" and now criticising the government for lifting the ban. The NDC is a confused political group. They have a 'bad' candidate for the upcoming elections. Hence, they are throwing dust into the eyes of the general public to revive their political fortune. According to the NPP:

Politicisation of everything coronavirus by the NDC was for their "political survival" as highlighted by the President of the Republic. Whenever the President addresses the nation on measures taken to combat the coronavirus, the NDC through former President Mahama, will organise a counter address using Facebook and the traditional media as if Ghana has a parallel government and President. The lifting of the partial lockdown was not political but a pragmatic step to protect and preserve life.

The easing of the restrictions was based on scientific data and advice. The participants were of the view that, the virus is fatal when the individual infected has a weak or slack immune system. The partial lockdown revealed that, majority of Ghanaians were either not feeding or were under-fed. Majority of Ghanaians live or survive on hand to mouth on a daily basis. The partial lockdown could no longer allow this category of people to work and feed to enable them boost their immune system. They were more likely to die from starvation than COVID-19. In the event of community spread, especially in the slum communities, the death toll could rise to uncontrollable levels. Hence, the best government could do under such a circumstance, was to lift the restrictions while observing other protocols, including social distancing and personal hygiene. Government's decision was subsequently supported by the Ghana Medical Association (G. M. A) and one of the leading testing centers on COVID-19 (i.e., Noguchi Memorial Centre for Medical Research). It is only the NDC and their 'political' surrogates who are yet to appreciate the rationale for government's decision. There was nothing political expediency that influenced the decision to lift the restriction on movements.

\section{Conceptualisation of Pathogenic Diseases}

Contagious diseases were 'philosophised' albeit ignorantly, among ancient people and even the contemporary Africa populace to be, punishment of the 'gods' or evil spirits in society. Hence, epidemics or pandemics were theorized based on culture and religious underpinnings. In rural and semi-urban areas in Africa in general and Ghana in particular, traditional authorities still attribute contagious disease transmission to a matrix of culture and religion [7]. Diseases such as cholera, cerebrospinal meningitis, measles, mumps, and chicken pox, are explained as retribution from the gods of the land for sins of society. Sacrifices (e.g., fowls, sheep, goats, cattle, cooked or uncooked food, Schnapps etc depending on the sacerdotal practices or cultural setting of a people) are offered to the gods to atone the 'sins' of society. This belief is a sharp contrast to scientific understanding of bacteria, fungus, germs, virus, and parasites as causative agents of epidemics or pandemics. In this paper, an epidemic is narrowly defined to mean, the spread of a pathogenic disease in a concentrated geographical area. Its spread is limited in a particular continent as the case of Ebola, SARS, MERS, anthrax, flu, among others. Pandemic is the global spread of a disease. Pandemic disease is unlimited in terms of scope and nature of spread. Such a disease appears to be prevalent worldwide. The purgatory of COVID-19 or SARS2 is an example of a pandemic that plagued countries across the world.

In recent times, global health has attracted the attention of scholars of international relations [7]. Accordingly, issues about global health has become ubiquitous in the international arena. The well-being of citizens in a state is a major determinant of the state's stability, economic growth and development. The spread of HIV/AIDS, SARS, Ebola Virus Disease (EVD) and currently, COVID-19 pandemic with its profound crippling effects on the global economy, security and politics have shaped the outlook of global forces on health. Humankind since the twilight of history is bogged or besieged with a variety of pathogenic diseases (e.g., these diseases according to virologists and medical professionals, are caused by bacteria, germs and viruses that invade the body of human species). Pathogenic or infectious diseases are those diseases that are transmitted from person to person, and are occasionally, from animals to humans. These pathogenic diseases virulently attack vital organs in humans, causes dysfunction of the organs and may lead to catastrophic deaths. The health of victims is restored timely, if appropriate remedies such as vaccines, antibiotics, surgery and physical distancing measures are deployed. Coronavirus, also called severe acute respiratory syndrome coronavirus, causes a highly contagious respiratory disease that is characterised by symptoms of fever, cough, persistent sneeze and muscle ache, often with progressive difficulty in breathing [8]. Generally speaking, pathogenic diseases are of two kinds natural and biological.

Humans are by nature gregarious. Human interaction with 
fellow beings is an involuntary act. Human interactions in the global system or across borders, has tremendously increased due to improvement in modern transportation systems around the world. This has made travelling, human interactions, global trade, aesthetic, tourism and exploration faster and easier. The world has shrunk to one big 'village' (globalisation). Events at one end of the globe, are inextricably linked to the rest of the system. Hence, the spread of infectious disease in any part of the global system, affects every part of the system and across national borders. The origin of COVID-19 is well documented. Yet, the viral disease leapfrogged to over two hundred countries across the globe. The devastating and crippling effects of the virus on the global economy, security, human life and families, cannot be overemphasised. Its negative ramifications are shared worldwide because of states' interconnectivity and cultural exchanges through education, tourism, military, economic, security and other common national interests.

Again, the change in demographics and the ever-growing demand for land for habitation and for agricultural purposes, has compelled some nation states to venture into forests originally inhabited by bats and other wild animals or birds the main feature of increased population growth in this modern world, is the ever-growing appetite for land and a drift to urbanisation and its resulting slums. Also, hunting and consumption of these wild animals and birds without safety protocols of the so-called 'bushmeat', increases the emergence of infectious diseases that are alien to known vaccines or resist existing vaccines and other medications for treatment. These animals and birds are said to have certain contagious diseases that can be transmitted from animals to humans; and from person to person. The origin of HIV/AIDS is theorised to have evolved from monkeys to human species; and transmitted from person to person through a labyrinth of mechanisms. Infectious (pathogenic) diseases were uncommon and also, a lowercase among ancient people, largely because of the modest population size. In contemporary times, the increase in population density across the globe, has necessitated human interaction or contacts as well as the invasion of land reserved for wildlife habitation. In the words of Washer (2010):

Growing populations are... forced to expand into territory previously uninhabited by humans such as virgin forests, where they can disturb zoonotic (animal) reservoirs of infections [9].

Viral infections that originate from zoonotic (animals) ecology to humans, usually records catastrophic death tolls, especially, when it is novel, and defies existing medications and/or vaccines for treatment. These infectious diseases are particularly fatal to the elderly in society, people with weak or low immunity, and people with underlying medical condition (s) such as HIV/AIDS, diabetes, Hepatitis, cancer, liver disease, etc. In the view of Washer (2010):

This growing population of people either suffering from chronic diseases, ... old age, resulted in a corresponding increase in immunocompromised people more vulnerable to infectious diseases $[9,2]$.
The novel COVID-19 has sent scientists throughout the world in a precipitation race to find a vaccine antidote to halt the effects of the disease as the death toll soars across the world. The virus continues to lay its cold hands on many people, as developed and developing countries look on pitiably and gloom fully. The elderly and people with weak or compromised immune system due to some underlying medical conditions, were/are worse affected in terms of statistics on the global and regional death toll in countries such as Italy, UK, France, Netherlands, Belgium, Germany, Brazil, the US, Russia, Iran, Egypt, Morocco, South Africa, Ghana, Nigeria, Burkina Faso, etc. It has to be categorically stated that, the author is by no means inferring that, young men and women without any underlying medical condition are immune and cannot be infected by COVID-19. Indeed, children under ten years of age in the US, have contracted the disease and subsequently lost their lives in the process.

Besides natural causes of pathogenic diseases, infectious diseases are also created from laboratories for the purposes of national defence. Technological advancement makes it possible for chemical, biological and nuclear weapons of varied forms to be created for subtle modern warfare. For instance, there has been several conspiracy theories regarding the coronavirus. While the US, the UK, Germany, France, Spain, Italy and other like-minded states, are of the view that, the current pandemic was created in Hubei province by Chinese scientists to deliberately 'punish' the world, other petit states are of the view that, COVID-19 may have emerged from a natural cause or human contact with bats, monkeys and other wild animals. The thrust of this paper is not to engage in these conspiracy theories. However, there is poignant evidence of the use of chemical and biological induced viruses that are fatal to human life. The use of bioterrorism accelerated in the aftermath of 9/11 attack on the US. Anthrax and lethal gas attacks across the globe increased phenomenally - examples include anthrax attack on members of Congress and Senators in the US, the use of bio-weapons in Syria, Yemen and Iraq.

\section{The Politics, Economics and Science Rationale of Lockdowns}

Lockdown or restrictions on the movement of people in a state, communities or whole cities or towns, does not by itself prevent a virus from infecting other people in society. What is urgently required is contact tracing mechanism, testing and treatment of isolated patients to ensure the reduction in the transmission of the virus from person to person and from animals to people. Many countries in Africa including Ghana, have learned bitter lessons (even though it is a necessity, unavoidable and painful decision) from the stalemated lockdowns and its ramifications on the state's stability, or the security threat it poses, as well as the socio-economic wellbeing of affected national populations. Political jabbing, extreme criticisms and partisanship during a pandemic - be it constructive or frivolous - of a ruling government by political 
opponents or the reverse, are daily routine political activity. For instance, the NPP while in opposition during the outbreak of the Ebola Virus Disease (EVD), were at their best in criticising the preparation and management of the pandemic by the then ruling National Democratic Congress. The politics of coronavirus in Ghana emerged soon after the World Health Organisation (W. H. O) declared the pathogenic as a Public Health Emergency of a global Concern.

Politically, the announcement of the partial lockdown of the economy by the government led to restriction of movements of people. The decision of government to implement a partial lockdown instead of a total curfew, inadvertently courted fervid debate between the ruling New Patriotic Party (N. P. P) and the main opposition political party (the National Democratic Congress). According to the NDC, the government erred in its handling of the pandemic. The party argued that, the partial lockdown is antithesis of international norm in the fight against COVID-19. It also defies logic from all perspectives. Just as the hotly contested political undertones of partial lockdown and total lockdown was about to die down, the government took another bold but controversial decision to lift the partial lockdown after three weeks in force. The reasons for lifting the ban on movements of people according to President Nana Addo Dankwa AkufoAddo are:

...in view of our ability to undertake aggressive contact tracing of infected persons, the enhancement of our capacity to test, the expansion in the numbers of our treatment and isolation centres, our better understanding of the dynamism of the virus, the ramping up of our domestic capacity to produce our own personal protective equipment, sanitises and medicines, the modest successes chalked at containing the spread of the virus in Accra in Kumasi, and the severe impact on the poor and vulnerable, I have taken the decision to lift the three (3) week old restriction on movements in the Greater Accra Metropolitan Area and Kasoa, and the Greater Kumasi Metropolitan Area and its contiguous districts, with effect from 1:00am on Monday, $20^{\text {th }}$ April ... [10].

The decision by the government to lift the partial lockdown in Accra and Kumasi attracted mixed reactions from health workers, politicians, civil society organisations and the media fraternity. There was however, a spontaneous jubilation from the poor and vulnerable persons across the affected communities in support of government decision to lift the partial restriction. For the poor and vulnerable persons, the lifting of the imposed restrictions meant the amelioration of three (3) weeks of suffering from stark poverty, hunger and death, restoration of economic livelihoods and human dignity. The poor, needy and vulnerable persons in the context of coronavirus pandemic battle, extended beyond the destitute or impoverished, homeless and mentally deranged persons in society. The scope is broadened to include roasted plantain sellers, petty traders, commercial drivers (e.g. trotro drivers) and cobblers whose survival is contingent on daily marriage of their business activities to put smiles on the face of their families.

The lifting of the ban on movements attracted a barrage of criticisms from the largest opposition political party - the National Democratic Congress. The Minority Members in the Ghanaian Parliament chastised the government for its lack of foresight in the handling of COVID-19 pandemic. According to the party, the lifting of restrictions was a recipe for disaster in terms of the spread of the virus and death. In a sharp response to the decision of government to lift the partial movement restrictions, the leader of the NDC tweeted:

Recent developments have made it clear, the extent of the spread of the virus. The last report put the number of confirmed cases at 834. Many health experts continue to suggest the necessity and appropriateness of an extension of the restrictions on movement [11].

The NDC and its communicators on various media platforms throughout the country lambasted the government for its policy decision. They contended that, the NDC would have done better in the management of the spread of the virus, given its experience in the handling of the Ebola Virus Disease (EVD) that plagued four (4) West African states in 2014. Was the NDC embroiled in political expedition to court the support and sympathy of the Ghanaian voter? Is the subsequent spike of the virus a vindication of the NDC? These questions posed, are premised on the 'fear' of the NDC that, lifting of the restriction on movements was to be an effective conduit for the spread of the coronavirus exponentially. There has been indeed, an astronomical increase (more than seven-fold) of confirmed cases of COVID-19 since the lifting of the restrictions on movements. The number of infected cases rose from 834 to 7,303 as at May 27, 2020. The additional numbers were recorded within one month (20 $0^{\text {th }}$ April, 2020 to $20^{\text {th }}$ May, 2020) after the lifting of the movement restrictions. The increased COVID19 cases also led to the pollicisation of hospitals (i.e., who built what, when and the number of health projects executed by the NPP and the NDC); nose masks and the supply of Personal Protective Equipment (PPEs). The NDC was of the view that, its flag bearer, thus former President Mahama, be accorded the credit for building hospitals across the country for which the current government is using as isolation centers for COVID-19 patients. The NDC challenged the ruling government to show just a single hospital project it built or constructed since they captured the levers of government in 2017. These stared up political debate between the ruling government and the largest opposition party in the news media. Instead of concentrating on the effective measures to combat COVID-19, the two main political parties (NPP and NDC), broached by the NDC, were embroiled in partisan expedition to score political points. Again, the NDC became the de facto champions in highlighting and criticising government 'inefficiencies' in the distribution of PPEs in the health sector.

The Ghana Medical Association (G. M. A), just like the NDC, expressed its disappointment in the President of the Republic for lifting the partial lockdown. The GMA earlier advocated extension of the partial lockdown after the 
association initially failed to influence the government to impose a dusk to dawn curfew to check the spread of the COVID-19. The GMA however, made a sharp 'U-Turn' of its criticisms, after having met and interacted with President Akufo-Addo. They backed off from their earlier stance, and subsequently expressed support to the government's decision to lift the restrictions it earlier opposed. It is unclear what might have influenced the decision of the GMA to change its stance on the status quo. In the midst of the politicisation of the COVID-19 pandemic, the government, through the Information Ministry, declared its disinterest to engage in coronavirus politics. Instead, the focus would be on how to defeat the COVID-19 that has the potential to wreak havoc on humanity (death); ravel national security; and weaken the manpower of the state if not well managed. In an attempt to rope the various political parties on board the pandemic fight, the President of the Republic extended invitations to the leaders of political parties to the seat of government for interaction. The discussions centered on the COVID-19 pandemic and the need to build consensus. The President made a profound statement and declared:

... it is essentially for us to have an opportunity to exchange information with each other, and, more than anything else, to agree on the measures that we can take as political leaders to ensure the unity of our nation. It is at this critical time, and to stress the need for solidarity amongst ourselves [10,2].

The above admonition from the President did not conciliate the political expedition of the two main political parties. The weekly and bi-weekly updates on measures and decisions of the government on COVID-19 by the President to the nation was interpreted by the NDC apparatchiks to be, subtle political canvass of votes ahead of the December, 2020 general election. There is always political discussion and its resulting political tensions and name calling on radio and television shows, whenever the President of the Republic update Ghanaians on the COVID-19. The media, while educating citizens on the protocols underpinning the pandemic spread, it also contribute immensely in stoking political tensions associated with the COVID-19. Some media houses invite panelists from the two main political parties to engage in crossfire debates at the expense of educating citizens and promoting the COVID-19 fight,

Lockdown of an economy - whether partial or total lockdown- has some bitter ramifications for the state and citizens at all levels. Lockdown of businesses due to a pandemic like COVID-19, has serious economic consequences on families, widespread poverty, starvation, misery and death. Technically speaking, the Ghanaian economy is not one that is robust enough to have sustained the various relief packages announced by the President of the Republic. Without financial inflows from tourism, import and export duties, taxes from industry and the informal sector, the state economy would not have been able to take care of worker's compensation, fund the health budget and general development, if the restrictions were not lifted. In the case of Ghana, workers in the informal sector dominate the economy.
These are the category of workers who survive on a daily wage for a living. They form a chunk of the vulnerable, poor and needy in the Ghanaian society. Hence, an extended lockdown, would have been catastrophic for this category of citizens. In his address, President Akufo-Addo stated among others:

At the end of the day, as the President of this country, I cannot ignore the impact this lockdown is having on several constituencies of our nation, especially those who we know are a very important part of the Ghanaian equation, the people who live on hand to mouth, those in the formal sector who need to have a day out in the market to be able to provide for their families [10, 3].

Besides the informal sector, many other poor and vulnerable persons in society, live on hand to mouth. Many other workers in the informal sector suffered from the lockdown due to unavailability of customers to purchase their wares or products because of the "stay at home" protocol, advocated by the W. H. O. and the Ghana Health Service. The lockdown policy affected immeasurably, the economic well-being of families and businesses in general. The abject poverty, hunger and starvation, family pressures, price gouge of foodstuffs, sanitizers and the fear of the unknown, had psychological trauma on the leadership of various families and, workers' unions. The lack of opportunities to work to fend for the family, led to a surge in domestic violence. The lifting of the restriction on movements caught the attention of the Ghana Trade Union Congress (T. U. C) - amalgamation of workers' association from varied sectors of the economy. The Secretary-General of the TUC on behalf of workers, lauded the President and his government's decision to lift the restriction of movement imposed on certain parts of the country. He stated that:

We have followed the developments in the country since the first two confirmed cases were announced and the measures you and your government have taken so far to deal with this major health crisis. The restrictions on movements have yielded some positive results and we are all witnesses to this. You have eased some of these restrictions and emphasized that other restrictions must be complied with strictly; we think it is the right thing to do, given the dire economic consequences of prolonged restrictions [12].

The Trade Union Congress was deluged with the economic consequences of the COVID-19 pandemic lockdown on businesses, and the mass suffering of workers and their dependents. While lockdown is the catchphrase and the 'new normal' for governments to adopt among an array of measures to stem the spread of COVID-19, the economic consequences of a lockdown has far-reaching ramifications on individual workers and their health. The feeding of the immediate family of workers within the three (3) week period was dire. It was therefore not surprising that the TUC supported government's decision to ease the restrictions. Again, the government's action to lift the ban on movements appeared to have made economic sense to many a people, except those who prioritized politics over butter and bread 
issues in the context of the COVID-19 pandemic.

Again, the lifting of the partial lockdown by the President received mixed reaction across the length and breadth of the country. The easing of the restrictions occurred at a time that the case count of Ghana was increasing exponentially. This generated political debate as expected, from the main opposition political parties. The NDC accused the ruling government of prioritising politics above science. The minority in Parliament were of the view that, the lifting of the ban on restrictions defies logic. The government response was that, it acted based on advice from health professionals and data available to it. The government's assertion was corroborated by Noguchi Memorial Centre for Medical Research - the leading Research Centre in COVID-19 testing located at the University of Ghana. According to the Centre, coronavirus is fatal for infected persons whose immunity is weak. In this perspective, the President of the Republic stated that:

The decision to impose restrictions on movement was backed by the data at hand, and the next course of action again, is backed by data and by science. Indeed, all that Government is doing is intended to achieve five (5) key objectives - limit and stop the importation of the virus; contain its spread; provide adequate care for the sick; limit the impact of the virus on social and economic life; and inspire the expansion of our domestic capability and deepen our self-reliance.

The President further stated that:

... there continues to be the deliberate dissemination of fake news, disinformation and outright lies by some unpatriotic citizens about the spread of the virus since its outbreak in the country. These acts are being orchestrated by those who hope to benefit by seeking to sow the seeds of panic and confusion amongst the populace at this time of national crisis. I have an unequivocal message for those involved in these despicable acts - put an immediate stop to it, or be held accountable for your actions [10, 4].

The President's concerns of "disinformation", "unpatriotic citizens", and "outright lies", even though the NDC was not mentioned specifically, many a Ghanaian inferred the statement to be attributable to the NDC. The President asserted that, the NDC was engaged in propaganda for its "political survival" in a bid to redeem its battered image since its humiliation as a political party in the 2016 general election.

\section{Way Forward}

The country is faced with a perilous invisible enemy reminiscent of an all-out war against the threat of a foreign invasion. This calls for all shoulders to be on the wheel in the quest to defeat the common enemy before the resort to the political ambiance. COVID-19 is no respecter of persons, religion, ethnic group, political party, or the social club one belongs to. The virus has no political coloration when it scavenges for victims in a community or society. There is therefore the need for the government, civil society organisations, religious groups, traditional leaders, local government authorities workers associations, student associations, health professional and the media to put all hands on deck to fight the COVID-19 pandemic that continuously threaten states survival through the crippling of economies, and by ifso facto, abject poverty and hunger of compatriots. Unless it is collectively agreed to disagree on the stringent measures, including aggressive education of citizens, the virus is likely kill many more people. The virus must not overrun and dead ahead of the state because of ideological and geo-political differences. In this conundrum, the government must take the following steps to bring every Ghanaian on board in its quest to defeat the COVID-19.

First, information flow concerning COVID-19, should be made known to all Ghanaians on a daily basis until such a time that the virus is defeated. The information on the pandemic should not only be on the regular update of the surge of confirmed infected cases, recoveries and death toll a function the Information Ministry and the Ministry of Health are executing with distinction, but must include education of citizens on selected Ghanaian languages to ensure the appreciation and dangers associated with the virus spread. At the moment, a large segment of the Ghanaian population is of the firm belief that, the infectious disease is limited to those returning from abroad, and people living in Accra, Kumasi and other big cities. This attitude is an anathema to the COVID-19 pandemic eradication efforts by the state. It is therefore imperative to widely educate citizens especially, those in the countryside, on the protocols of the virus. Education of citizens on the pandemic would certainly spare many people from contracting the disease; save lives and state resources; confine the disease; and subsequent defeat of the virus from the shores of the Republic.

In furtherance, transparency and accountability are key in the fight against COVID-19. It enables stakeholders to focus on the pandemic at hand that threaten the human survival worldwide. The presidential candidate of the NDC (former President, John Dramani Mahama) has on countless times, indicated his desire to audit all financial assistance from local and international sources in relation to the COVID-19 fight if he wins the December, 2020 polls. The former President was particularly referring to parliamentary approval for Ghana government to access USD \$100 million and USD\$1 billion loan facilities from the IMF/World Bank. The bickering and subsequent parliamentary approval of a request by the Finance Ministry to withdraw additional USD200 million from the Ghana Stabilization Fund (GSF) to support the Coronavirus Alleviation Programme (CAP), are deemed suspicious from the perspective of the NDC. Indeed, the Minority group in Parliament at a press briefing (May 11, 2020) accused the government of "misapplying funds, both local and International" in connection with COVID-19. The politics and the suspicion regarding management of various donations and the loan facilities sourced from the International Monetary Fund (IMF) and the World Bank, has heightened partisan connotations by the NDC. This has the propensity to divert the attention of government in its quest 
to defeat the ever-growing threat of the COVID-19. In order to forestall these setbacks, government through the Ministry of Finance, should consider making known to the Ghanaian populace, how the Ministry of Finance disburses IMF/World Bank assistance, in relation to the COVID-19 pandemic.

The government in its quest to get individuals and institutions on board to fight the COVID-19 pandemic, through an act of Parliament (Act 1013), established the "COVID-19 National Trust Fund". The thrust and purpose of its establishment was to receive donations from individuals and institutions to compliment the efforts of the state in the battle against COVID-19. The Trust Fund is chaired by Her Ladyship Justice (Retired) Sophia Akuffo. To ensure transparency and accountability, the Chairperson declared at the forecourt of the seat of government that:

We are happy to announce that the Fund has so far in addition to generous gifts in kind, the details of which we are more than willing to share with any interested person. We have received an amount of Forty-Four Million, Nine Hundred Thousand Ghana Cedis (GHS 44,900,000.00). The Board of Trustees will ensure the judicious and transparent application of all monies and other resources received for their intended purposes [13].

The above supposition or declaration by the Chairperson is reassuring. The willingness to share with interested person or persons on the allocation of funds in relation to the COVID19 fight, deepens transparency and accountability. It reduces or eliminates suspicion and political distrust and tensions. Transparency and accountability build confidence of donors. It depicts a picture that funds received, would be applied or used judiciously and appropriately. It encourages other individuals and institutions (who, due to suspicions of probable diversion of funds by state officials) to come out of their shells, and donate for a common course of defeating the pandemic.

Inclusivity is one of the key tenets, and the catchphrase in modern democratic governance. The government without doubt, has engaged relevant stakeholders since Ghana recorded its first confirmed cases of the novel coronavirus in March, 2020. The President of the Republic, and the COVID-19 taskforce, have met with the Ghana Medical Association (GMA), Ghana Trade Union Congress (TUC), Leaders of Political Parties, various Religious Groups, Market Women Association, Captains of Industry, National House of Chiefs, National Union of Ghana Students (NUGS), University Teachers Association of Ghana (UTAG), Representatives of Teacher Unions, Ghana Registered Nurses and Midwives Association (GRNMA), Ghana Football Association (GFA) among others. The import of these engagements was to afford the government the opportunity to explain its policies on the COVID-19 fight, while tapping relevant feedback on its policy on the pandemic from the various stakeholders. The meetings were to foster consensus building between the state and civil society organisations on COVID-19. While these engagements are plausible, it would be proper if government and other state officials at the forefront of the pandemic fight, integrate some leaders of the various political parties and civil society organisations with relevant knowledge onto the management of the COVID-19. The rationale is to water down 'political suspicion' associated with COVID-19, while focusing on defeating the invisible common enemy.

\section{Conclusion}

The three-week partial lockdown imposed by the government in some selected cities and their environs, was very unpopular among the participants of this study. This finding is in line with the global trend of citizen's protest against lockdowns and other restrictions. The rise in the number of COVID-19 pandemic cases in Ghana since the first reported cases in March, 2020, is mind-boggling. The droves in confirmed cases on a daily and weekly basis presuppose that, the state need to intensify its surveillance and more drastic measures ought to be taken to further contain the spread of the disease. COVID-19 death toll may not be as catastrophic as malaria, Spanish Flu, HIV/AIDS and Cholera, but the purgatory of the virus has the potential to weaken the workforce of a state and paralyze its economy. Never in the history of infectious diseases has the world witnessed total grounding of the world economy, including the aviation industry, hospitality and education. Hence, COVID-19 poses a serious national security threat. In times of a pandemic outbreak, the first priority should be to test, isolate, and treat patients [14]. Health issues cannot be traded with partisan politics, geopolitics, sectionalism, ethnicity, or religious considerations. COVID-19 is a withering pandemic root and branch. It requires massive and collective support from all segments of society (including leadership of various political parties) to reverse the status quo and save humanity from destruction. The usual coterie of partisan expedition in the midst of a pandemic, political puerility, irreverent, laxity and levity on national discourse must be shelved until the invisible enemy (coronavirus) is completely contained. The state cannot, and must not be distracted by partisan expedition in the course of the battle against COVID-19. It does not make any political sense to focus on winning an election and probably govern cemeteries while the vast majority of citizens are paralyzed or weakened by a pandemic like coronavirus. Hence, the most appropriate approach to combating the COVID-19, is for every citizen to participate and give every support to government to minimise the profound crippling effects on human life, the state economy and the potential threat to national security. The effects of the pandemic cannot be treated as saveloy or tea party by political leadership. COVID-19 has both negative and positive impacts on health, security, economy, social relation and human capital. The bitter COVID-19 didactic is the need for states to consciously invest in health systems at home and abroad, for posterity.

\section{Declaration of Competing Interest}

No competing interest is associated with this manuscript. 


\section{References}

[1] Leon, J. K. (2015). The rise of global health: The evolution of effective collection action. Albany: State University of New York Press.

[2] Brown, K. \& Wang, R. C. (2020). Politics and science: The case of China and the coronavirus. Asian Affairs, 51: 2, $247-$ 264.

[3] Biscop, S. (2020). Coronavirus and power: The impact on international politics. Brussels: EGMONT Royal Institute of International Relations, No. 126, pp 1.

[4] El Zowalaty, M. E. \& Josf, D. J. (2020). From SARS to COVID-19: A previously unknown SARS-related coronavirus (SARS-COV-2) of pandemic potential infecting humans Call for a o. ne health approach ELSEVIER B. V., pp 1-6. Accessed: https://doi.org/10.1016/j.onehlt.2020.100124.

[5] Braimah, A. I. (2020). Free education policy in a neoliberal global environment: Synergies and contradictions. Unpublished manuscript.

[6] Braimah, A. I. \& Bawah, A, S. (2019). Violent death in the lives of police officers in Ghana: An evidence-based study, International Journal of Scientific Research and Management, Vol. 7, No, 5, pp 491-500.
[7] Karamanou, M., Panayiotakopoulos, G., Tsoucalas, G., Kousoulis, A. A. \& Androutsos. G. (2012). From miasmas to germs: A historical approach to theories of infectious disease transmission. Le Infezioni in Medicina, n. 1, 52-56.

[8] Washer, P. (2010). Emerging infectious diseases and society. NY: Palgrave Macmillan.

[9] Coronavirus, (2012). Encyclopaedia Britannica. Encyclopaedia Britannica Ultimate Reference Suite. Chicago: Encyclopedia Britannica.

[10] Government of Ghana (2020). Address to the nation by president of the republic Nana Addo Dankwa Akufo-Addo, on updates to Ghana's enhanced response to the coronavirus pandemic. Sunday, $19^{\text {th }}$ April, 2020.

[11] Mahama, J. D. (2020). Tweet by former president John Mahama on lifting of restriction on movements in Greater Accra and Greater Kumasi, Accra, Ghana.

[12] Ghana Trade Union Congress (2020). Interaction with President Akufo-Addo at the Jubilee House, Accra, Ghana.

[13] Akuffo, S. (2020). Speech delivered at the Seat of Government by Chairperson of 'CVID-19 National Trust Fund', Accra, Ghana.

[14] Monaco, L. (2020). Pandemic disease is a threat to national security: Washington should treat it like one. Foreign Affairs Magazine. 